\title{
Construction of Corynebacterium glutamicum cells as containers encapsulating dsRNA overexpressed for agricultural pest control
}

\author{
Shuhei Hashiro ${ }^{1}$ (D) Mayu Mitsuhashi ${ }^{1} \cdot$ Yasuhiko Chikami $^{2,3}$ (D) $\cdot$ Haruka Kawaguchi $^{2}$ (D) Teruyuki Niimi $^{2,3}$ (D) \\ Hisashi Yasueda ${ }^{1,4}$ (B)
}

Received: 4 July 2019 / Revised: 21 August 2019 / Accepted: 30 August 2019/Published online: 5 September 2019

(C) The Author(s) 2019

\begin{abstract}
Double-stranded RNA (dsRNA) inducing RNA interference (RNAi) is expected to be applicable to management of agricultural pests. In this study, we selected a ladybird beetle, Henosepilachna vigintioctopunctata, as a model target pest that devours vegetable leaves, and examined the effects of feeding the pest sterilized microbes highly accumulating a target dsRNA for RNAi induction. We constructed an efficient production system for diap $1 *$-dsRNA, which suppresses expression of the essential gene diap1 (encoding death-associated inhibitor of apoptosis protein 1) in $H$. vigintioctopunctata, using an industrial strain of Corynebacterium glutamicum as the host microbe. The diap $1 *$-dsRNA was overproduced in C. glutamicum by convergent transcription using a strong promoter derived from corynephage BFK20, and the amount of dsRNA accumulated in fermented cells reached about $75 \mathrm{mg}$ per liter of culture. In addition, we developed a convenient method for stabilizing the dsRNA within the microbes by simply sterilizing the diap $1 *$-dsRNA-expressing $C$. glutamicum cells with ethanol. When the sterilized microbes containing diap ${ }^{*}$-dsRNA were fed to larvae of $H$. vigintioctopunctata, diapl expression in the pest was suppressed, and the leaffeeding activity of the larvae declined. These results suggest that this system is capable of producing stabilized dsRNA for RNAi at low cost, and it will open a way to practical application of dsRNA as an environmentally-friendly agricultural insecticide.
\end{abstract}

Keywords RNA-based pesticide - dsRNA production · Corynebacterium glutamicum · Henosepilachna vigintioctopunctata . Inhibitor of apoptosis $\cdot$ Pest control

Electronic supplementary material The online version of this article (https://doi.org/10.1007/s00253-019-10113-9) contains supplementary material, which is available to authorized users.

Hisashi Yasueda

hisashi_yasueda@ajinomoto.com

Mayu Mitsuhashi

mayu_mitsuhashi@ajinomoto.com

1 Institute for Innovation, Ajinomoto Co., Inc., 1-1, Suzuki-cho, Kawasaki-ku, Kawasaki 210-8681, Japan

2 Division of Evolutionary Developmental Biology, National Institute for Basic Biology, Nishigonaka 38, Myodaiji,

Okazaki, Aichi 444-8585, Japan

3 Department of Basic Biology, School of Life Science, SOKENDAI (The Graduate University for Advanced Studies), Nishigonaka 38, Myodaiji, Okazaki, Aichi 444-8585, Japan

4 Research and Development Center for Precision Medicine, University of Tsukuba, 1-2, Kasuga, Tsukuba-shi, Ibaraki 305-8550, Japan

\section{Introduction}

Many powerful chemical pesticides have been used to combat pests in agriculture. Although they have brought great benefits to crop cultivation, they also have various undesirable environmental consequences, for example, effects on beneficial insects and soil microbes and the emergence of pesticideresistant pests (Woodcock et al. 2016; Alyokhin et al. 2008). Thus, the development of environmentally-friendly pest control methods that replace conventional chemical pesticides is desired and required. Recently, RNA has attracted attention as a potential candidate for pest control. When RNA interference (RNAi) by double-stranded RNA (dsRNA) is induced with respect to a gene essential for the growth of a target pest, expression of that gene is suppressed, and, as a result, the growth of the pest is inhibited. Thus, RNA molecules having such a function can be called RNA-based pesticides or RNA insecticides (Palli 2014; Gu and Knipple 2013).

The ladybird beetle Henosepilachna vigintioctopunctata is an agricultural pest, since the insect exclusively feeds on 
leaves of Solanaceae crops such as potato, tomato, eggplant, and so on. It is one of the most destructive pests found in Japan, China, India, and other countries and causes considerable economic damage, especially in vegetable cultivation (Wang et al. 2018; Jeyasankar et al. 2014). The pest becomes the adult from pupa after four molting stages of larvae (Venkatesha 2006), and both larvae and adults are known to eat the epidermal tissues of vegetable leaves greedily. Thus, we selected $H$. vigintioctopunctata as a model pest for targeting by RNA-based pesticide, and we have been studying the effect of dsRNA for RNAi on this pest. In previous work, we indicated that the leaf-eating activity of $H$. vigintioctopunctata could be efficiently suppressed by feeding the insect dsRNA corresponding to part of the diapl (deathassociated inhibitor of apoptosis protein 1) gene (Niimi et al. 2015; Chikami et al. 2019). The diap1 gene product interacts with the programmed cell death (PCD)-caspases and plays a role in proper function of the PCD process (Kumar and Cakouros 2004), which is particularly important in the metabolism of insects; disruption of DIAP1 function induces cell death. The dsRNA used in the previous study was prepared by in vitro enzymatic synthesis using a diap 1-cDNA fragment which we originally cloned from $H$. vigintioctopunctata (Niimi et al. 2015).

So far, growth inhibition of various insects (crop pests, ants, termites, and so on) through RNAi action by dsRNA has been reported (Zhou et al. 2008; Katoch et al. 2013; Bolognesi et al. 2012; Christiaens et al. 2016; Sun Miguel and Scott 2016; Knorr et al. 2018; Tariq et al. 2019). The preparation method of such dsRNAs was exclusively based on an in vitro $\mathrm{T} 7$ transcription system or a similar system using the T7 RNA polymerase/promoter combination in the host microbe Escherichia coli (Zhu et al. 2011; Ratzka et al. 2013; Tenllado et al. 2003). However, these methods are not fully satisfactory in terms of manufacturing cost and robustness in mass production of target dsRNAs. Reduction of the production cost of dsRNA is the first crucial challenge in its practical application in agriculture.

In previous study, we have succeeded in overproducing recombinant RNA molecules in Corynebacterium glutamicum having an efficient RNA expression system equipped with strong promoter F1, derived from corynephage BFK20 (Hashiro et al. 2019a, b). Although the model RNA overexpressed was single-stranded (ss) with double-stranded structures in part, accumulation of the target RNA reached about $300 \mathrm{mg}$ per liter of culture. C. glutamicum is well known as a microbe capable of overproducing amino acids at very low cost. The strain is nonpathogenic, safe, robust in large-scale fermentation, and its use benefits from the experience of industrial application for decades (Ikeda and Takeno 2013; Yasueda 2014; Lee and Wendisch 2017). Therefore, based on our C. glutamicum RNA expression system, we aimed to construct an efficient preparation system for dsRNA for RNAi pesticide action in agriculture.

Additionally, when dsRNA for pest control is sprayed on agricultural crops, improvement of dsRNA stability in ambient conditions is required. To reduce damage to naked RNA molecules by exogenous ribonucleases (RNases) or ultraviolet rays, some simple device to prevent the degradation as much as possible is necessary. Mitter et al. (2017) reported improvement of dsRNA stability with a special newly developed fine clay nanosheet. By employing the nanosheet as a dsRNA carrier, they achieved prolonged stability of dsRNA sprayed onto leaves and effective RNAi action. There is also a known method using heat-sterilized $E$. coli cells in which a target dsRNA was accumulated and then sprayed on fields without extracting the dsRNA from the microbial cells (Zhu et al. 2011). The method of directly using microbes containing a target dsRNA could reduce the cost of preparing the dsRNA for agricultural application.

In this study, as another method of providing stabilized dsRNA for practical use, we attempted to simply treat dsRNA-producing C. glutamicum cells with ethanol or methanol. It was found that stabilization of the dsRNA inside the cells occurred simultaneously with the alcohol treatment that resulted in bacterial killing. Thus, we here report an inexpensive preparation method for dsRNA that can be applied in agricultural uses in the future.

\section{Materials and methods}

\section{Bacterial strains, plasmids, DNA primers, and media}

Bacterial strains and plasmids used in this study are listed in Table 1. C. glutamicum 2256L $\Delta r n c$, which is a strain deficient in RNase III (the $r n c$ gene product, mainly involved in dsRNA degradation), was used as the host strain for dsRNA production. C. glutamicum strains were routinely grown on CM-Dex medium (Chinen et al. 2007) in a test tube at $30^{\circ} \mathrm{C}$ and also cultured in a jar fermentor using RPB1 medium (Hashiro et al. 2019b). Escherichia coli JM109 (Takara Bio, Shiga, Japan) was used for construction of recombinant plasmids and cultured in Luria-Bertani medium at $37^{\circ} \mathrm{C}$. When appropriate, antibiotics were added as follows: chloramphenicol $(\mathrm{Cm})$ at $5 \mathrm{mg} / \mathrm{L}$ and $20 \mathrm{mg} / \mathrm{L}$ for $C$. glutamicum and E. coli, respectively, and ampicillin (Ap) at $100 \mathrm{mg} / \mathrm{L}$ for E. coli. Plasmid $\mathrm{pVC7H2}$, which is a high copy number mutant plasmid derived from $C$. glutamicum/E. coli shuttle vector pVC7N, was used as the vector for dsRNA expression. Plasmid pGEM-RD2 was used for evaluation of plasmid copy number in C. glutamicum. All DNA primers used in this study are listed in Supplemental Table S1 and were obtained from Eurofins Genomics (Tokyo, Japan). 
Table 1 Bacterial strains and plasmids used in this study

\begin{tabular}{|c|c|c|}
\hline Strain or plasmid & Relevant characteristic(s) & Reference \\
\hline \multicolumn{3}{|l|}{ Strain } \\
\hline \multicolumn{3}{|c|}{ Corynebacterium glutamicum } \\
\hline 2256 & ATCC 13869, AJ1151, wild-type strain & Nishio et al. (2017) \\
\hline $2256 \mathrm{~L}$ & $\begin{array}{l}2256 \text { derivative cured of cryptic plasmid } \\
\text { pAM330N }\end{array}$ & Hashiro et al. (2019a) \\
\hline $2256 \mathrm{~L} \Delta r n c$ & $r n c$ mutant of $2256 \mathrm{~L}$ & Hashiro et al. (2019b) \\
\hline \multicolumn{3}{|l|}{ Escherichia coli } \\
\hline JM109 & $\begin{array}{l}\text { endA1, recA1, gyrA96, thi, hsdR17 }\left(\mathrm{r}_{\mathrm{k}}^{-},\right. \\
\left.\mathrm{m}_{\mathrm{k}}^{+}\right), \operatorname{relA} 1, \operatorname{supE} 44, \lambda^{-}, \Delta \\
\quad \text { (lac-proAB), } \mathrm{F}^{\prime}\left[\operatorname{traD} 36, \operatorname{proAB}^{+}, \text {lacl }^{\mathrm{q}} \text {, }\right. \\
\text { lacZ } \Delta \mathrm{M} 15]\end{array}$ & Takara-Bio (Shiga, Japan) \\
\hline \multicolumn{3}{|l|}{ Plasmid } \\
\hline pAM330N & Cryptic plasmid in C. glutamicum 2256 & Hashiro et al. (2019a) \\
\hline $\mathrm{pVC} 7 \mathrm{~N}$ & $\begin{array}{l}\text { C. glutamicum-E. coli shuttle vector } \\
\text { derived from pAM330N and } \\
\text { pHSG329; } \mathrm{Cm}^{\mathrm{r}}\end{array}$ & Hashiro et al. (2019a) \\
\hline pVC-U1A*-1 & $\begin{array}{l}\text { pVC7N derivative carrying F1 promoter } \\
\text { derived from BFK20; } \mathrm{Cm}^{\mathrm{r}}\end{array}$ & Hashiro et al. (2019b) \\
\hline $\mathrm{pVC} 7 \mathrm{H} 2$ & $\mathrm{pVC} 7 \mathrm{~N}$ copA2 mutant; $\mathrm{Cm}^{\mathrm{r}}$ & Hashiro et al. (2019a) \\
\hline pVC-Pf1-HvIap & $\begin{array}{l}\mathrm{pVC} 7 \mathrm{~N} \text { derivative carrying part of the } \\
\text { diap1-cDNA and } \mathrm{F} 1 \text { promoter; } \mathrm{Cm}^{\mathrm{r}}\end{array}$ & This study \\
\hline pVH2-Pf1rev & $\begin{array}{l}\text { pVC7H2 derivative carrying F1 } \\
\text { promoter derived from BFK20; } \mathrm{Cm}^{\mathrm{r}}\end{array}$ & This study \\
\hline pVH2-KX-Pf1rev & $\begin{array}{l}\text { pVH2-Pfl rev derivative carrying XhoI } \\
\text { and } K p n I \text { sites downstream of } \mathrm{F} 1 \\
\text { promoter; } \mathrm{Cm}^{\mathrm{r}}\end{array}$ & This study \\
\hline pVH2-HvIap-1 & $\begin{array}{l}\mathrm{pVC} 7 \mathrm{H} 2 \text { derivative carrying } \\
\text { diap1-dsRNA expression unit; } \mathrm{Cm}^{\mathrm{r}}\end{array}$ & This study \\
\hline pGEM-T Easy & Cloning vector, $\mathrm{Ap}^{\mathrm{r}}$ & Promega (Tokyo, Japan) \\
\hline pGEM-RD2 & $\begin{array}{l}\text { pGEM-T Easy derivative containing } \\
\text { repA gene fragment from pAM } 330 \mathrm{~N} \\
\text { and dnaA gene fragment from } \\
\text { C. glutamicum } 2256 \mathrm{~L} ; \mathrm{Ap}^{\mathrm{r}}\end{array}$ & Hashiro et al. (2019a) \\
\hline
\end{tabular}

$\mathrm{Cm}^{r}$ resistance to chloramphenicol, $\mathrm{Ap}^{r}$ resistance to ampicillin

\section{Insect}

H. vigintioctopunctata adults were collected at the National Institute for Basic Biology (Aichi, Japan) or Kumamoto University (Kumamoto, Japan). We established a line in the laboratory that was used for all experiments on the effects of dsRNA on the pest. They were reared on potato leaves at $25{ }^{\circ} \mathrm{C}$. Larvae used in this study were derived from a few batches of eggs and were starved after second molting.

\section{Plasmid construction}

RNA expression plasmid pVH2-HvIap-1 was constructed as follows. A DNA fragment (about $110 \mathrm{bp}$ ) containing the F1 promoter region was amplified by PCR using $\mathrm{pVC}-\mathrm{U} 1 \mathrm{~A} *-1$ (Table 1) as the template and primers P01 and P02. Next, the target diap $1 *$-DNA fragment, part of the diapl gene of $H$. vigintioctopunctata (DDBJ acc. no. LC473084) (Supplemental Fig. S1) (Niimi et al. 2015), was obtained by
PCR using a diap1-cDNA fragment as the template and primers $\mathrm{P} 03$ and $\mathrm{P} 04$. Using pVC7N as the template, a vector DNA fragment was obtained by PCR using primers P05 and P06. Then, the above three DNA fragments were linked by InFusion Ligation (Takara Bio) to construct pVC-Pf1-HvIap. Another DNA fragment containing the $\mathrm{F} 1$ promoter region was amplified by PCR using pVC-U1A*-1 as the template and primers P07 and P08. This DNA fragment was ligated with a vector fragment amplified by PCR with primers P05 and $\mathrm{P} 11$ using pVC7H2 as the template to construct pVH2Pflrev. This plasmid was subjected to inverse PCR amplification with primers P05 and P09; then, the amplified DNA fragment was treated with $D p n I$ and phosphorylated at the 5'- ends to construct $\mathrm{pVH} 2-\mathrm{KX}-\mathrm{Pf} 1 \mathrm{rev}$ by self-ligation of the processed DNA fragment. Next, using pVC-Pf1-HvIap as the template, PCR amplification was performed with primers P10 and P12 to prepare a DNA fragment containing the F1 promoter and diap $1 *$-DNA region. Finally, this DNA fragment and pVH2-KX-Pf1rev were treated with restriction enzymes 
XhoI and KpnI, and the DNA fragments were ligated with T4 ligase (Toyobo, Osaka, Japan) to construct plasmid pVH2HvIap-1 (Fig. 1a). Thus, an expression system for diapl*dsRNA was constructed in which two F1 promoters faced each other across the partial diapl coding fragment. The polymerase used for PCR in this study was PrimeSTAR GXL DNA polymerase (Takara Bio). The constructed plasmid was transformed into C. glutamicum strain $2256 \Delta r n c$ by electroporation.

\section{Production of dsRNA and PAGE analysis}

For small-scale cultivation using test tubes, transformants were cultured in $2 \mathrm{~mL}$ of CM-Dex medium containing $\mathrm{Cm}$ at $30^{\circ} \mathrm{C}$ for $18 \mathrm{~h}$, and total RNA was prepared from $0.2 \mathrm{~mL}$ of the culture broth as described previously (Hashiro et al. $2019 b)$. Total RNA solution ( $1 \mu \mathrm{L}$ ) was mixed with $7 \mu \mathrm{L}$ of $150 \mathrm{mM} \mathrm{NaCl}$ and $2 \mu \mathrm{L}$ of Hi-Density TBE sample buffer (Thermo Fisher, Tokyo, Japan), and then, the sample was analyzed by $6 \%$ nondenaturing PAGE (Thermo Fisher), followed by staining with SYBR Green II Nucleic Acid Gel Stain (Takara Bio). Batch fermentation using a BSS-01NP fermentor (ABLE Co., Tokyo, Japan) was performed in $0.3 \mathrm{~L}$ of RPB1 medium containing $40 \mathrm{~g} / \mathrm{L}$ L-glucose at $30{ }^{\circ} \mathrm{C}$, as described previously (Hashiro et al. 2019b). Cell growth was monitored by measuring the optical density of the culture at $620 \mathrm{~nm}\left(\mathrm{OD}_{620}\right)$ after 101-fold dilution of the culture with $0.2 \mathrm{M} \mathrm{HCl}$. Quantification of produced RNA was carried out by PAGE analysis using DynaMarker dsRNA (BioDynamics Lab., Tokyo, Japan) as a standard for the calculation (Hashiro et al. 2019b). The copy number of plasmid and the ratio of segregates in culture broth after fermentation

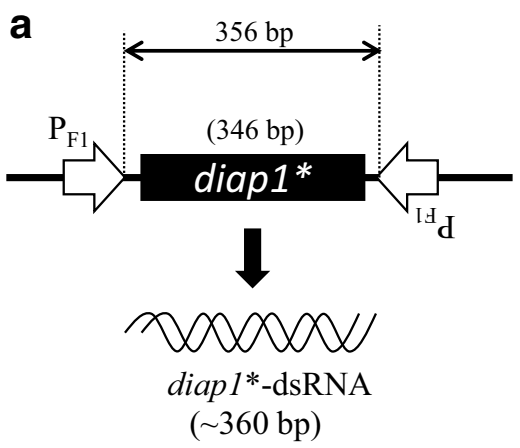

Fig. 1 Expression of diap 1 *-dsRNA by Corynebacterium glutamicum. a Structure of diap $1 *$-dsRNA expression system in pVH2-HvIap-1. Two $\mathrm{F} 1$ promoters $\left(\mathrm{P}_{\mathrm{F} 1}\right)$ are indicated by open arrows facing each other. diap $1 *$ represents part of the diap1-cDNA region. b PAGE-analysis of produced diap $1 *$-dsRNA. Lane $\mathrm{M}$ shows size markers of doublestranded RNAs. Lanes 1 and 2 are total RNA fractions from were determined as described previously (Hashiro and Yasueda 2018; Hashiro et al. 2019a).

\section{RT-PCR}

One-step RT-PCR was performed with $\mathrm{r}$ Tth DNA polymerase according to the manufacturer's protocol (Toyobo) to indicate the presence of an RNA region specific for the diapl gene. The sample RNA as template for reverse transcription was purified from a PAGE gel on which total RNA from C. glutamicum 2256L $\Delta r n c / p V H 2-H v I a p-1$ was electrophoresed. After the purified RNA sample $(2 \mu \mathrm{g})$ was treated with RNase-free DNase I (Qiagen, Tokyo, Japan) and extracted with TRIzol reagent (Thermo Fisher), the RNA (at concentrations in a serial tenfold dilution from 0.001 to $10 \mathrm{ng}$, as shown in Supplemental Fig. S2c) was denatured at $90{ }^{\circ} \mathrm{C}$ for $30 \mathrm{~s}$, followed by reverse transcription at $60{ }^{\circ} \mathrm{C}$ for $30 \mathrm{~min}$ in $50 \mu \mathrm{L}$ of reaction buffer containing $10 \mathrm{pmol}$ of each primer (P13 and P14), $2.5 \mathrm{mM}$ manganese (II) acetate, and $5 \mathrm{U}$ rTth DNA polymerase. After the denaturation, the generated cDNA was then amplified by 30 cycles of denaturation at $94{ }^{\circ} \mathrm{C}$ for $30 \mathrm{~s}$, annealing at $60{ }^{\circ} \mathrm{C}$ for $30 \mathrm{~s}$ and extension at $72{ }^{\circ} \mathrm{C}$ for $30 \mathrm{~s}$, following by incubation at $72{ }^{\circ} \mathrm{C}$ for $7 \mathrm{~min}$. The products were electrophoresed on a $2 \%$ agarose gel with DNA size marker (1 kb Plus DNA ladder, Thermo Fisher).

\section{RNase digestion}

RNase digestion experiments using RNase III (Thermo Fisher) and RNase A (Promega, Tokyo, Japan) were carried out to characterize the structural features of the produced recombinant RNA. Total RNA (1.6 $\mu \mathrm{g})$ extracted

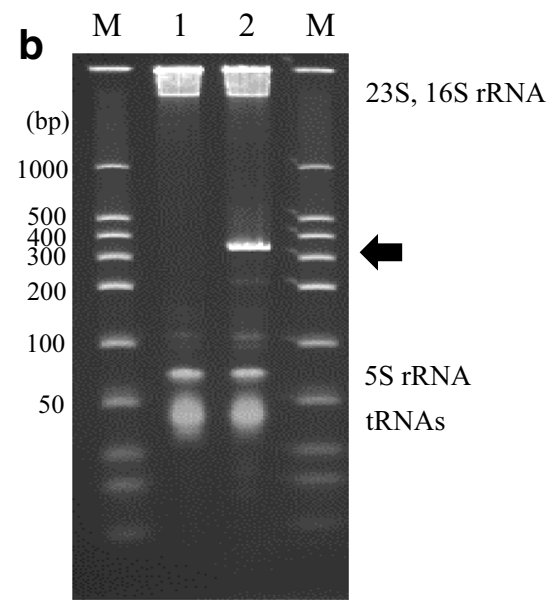

C. glutamicum strains 2256L $\Delta r n c$ harboring pVC7H2 as a control and pVH2-HvIap-1, respectively. A prominent RNA band corresponding to diap $1 *$-dsRNA is indicated with an arrow, and intrinsic RNA species (23S rRNA, 16S rRNA, 5S rRNA, and tRNAs) from host cells are also indicated 
from dsRNA-producing cells was digested at $25{ }^{\circ} \mathrm{C}$ for $30 \mathrm{~min}$ in $15 \mu \mathrm{L}$ reaction solution with $1000 \mathrm{U}$ of RNase A. In RNase III digestion, the RNA sample was reacted with RNase III (500 U) at $37{ }^{\circ} \mathrm{C}$ for $2 \mathrm{~h}$ in $16 \mu \mathrm{L}$ reaction solution containing $10 \mathrm{mM}$ Tris- $\mathrm{HCl}(\mathrm{pH} 7.5)$, $10 \mathrm{mM}$ EDTA, and $100 \mathrm{mM} \mathrm{NaCl}$. Both digestion reactions were loaded on a $6 \%$ acrylamide gel after addition of loading buffer (Hi-Density TBE sample buffer).

\section{Treatment of C. glutamicum cells with alcohol}

C. glutamicum 2256L $\Delta r n c / p V H 2-H v I a p-1$ and the control strain C. glutamicum 2256L $\Delta r n c / p V C 7 H 2$ were cultured in test tubes as described above. After $0.2 \mathrm{~mL}$ of the culture broth were centrifuged $(13,800 \times \mathrm{g}, 2 \mathrm{~min})$ to collect the cells, $1 \mathrm{~mL}$ of $10 \mathrm{mM}$ phosphate buffer solution ( $\mathrm{pH}$ 6.8) or buffer solution containing each concentration of alcohol (ethanol or methanol, from 10 to $95 \%$ [v/v], as indicated in Fig. 4) was added to the cell pellet at $20^{\circ} \mathrm{C}$, and then the cells were thoroughly resuspended. The cell concentration during the alcohol treatment was about $10^{9}$ cells $/ \mathrm{mL}$ in the reaction tube, and the suspension was allowed to stand at $20^{\circ} \mathrm{C}$ for $10 \mathrm{~min}$. After the treatment, the cell suspension was centrifuged to remove the supernatant. To examine the survival rate of treated cells, $0.2 \mathrm{~mL}$ of CM-Dex medium was immediately added to the cell pellet and then $0.1 \mathrm{~mL}$ of the suspension was spread and cultured on CM-Dex agar medium at $30{ }^{\circ} \mathrm{C}$ for $48 \mathrm{~h}$.

Evaluation of dsRNA stability in the alcohol-treated cells was performed as follows: each cell pellet treated with alcohol was incubated at $20^{\circ} \mathrm{C}$ for an additional $24 \mathrm{~h}$. After the incubation, the total RNA was extracted from the incubated cells and analyzed by $6 \%$ PAGE for detection of the target dsRNA band. When preparing the large amount of dsRNA-containing cells necessary for feeding to insect larvae, such sterilized microbial cells were prepared from $1.5 \mathrm{~mL}$ of culture medium.

\section{Heat treatment of $C$. glutamicum cells}

C. glutamicum cells containing target dsRNA and the control strain were sterilized by heating as follows: $0.2 \mathrm{~mL}$ of the culture medium was placed into a microtube and centrifuged in the same manner as described above. The cells were washed with $1 \mathrm{~mL}$ of $10 \mathrm{mM}$ phosphate buffer solution $\left(\mathrm{pH}\right.$ 6.8) and then centrifuged again at $4{ }^{\circ} \mathrm{C}$ to obtain the microbial cells. The sample was placed into a heat block (Dry Thermounit DTU-1B; TAITEC Co., Saitama, Japan) at $100{ }^{\circ} \mathrm{C}$ and incubated for $30 \mathrm{~min}$ for sterilization. After cooling to room temperature, $0.2 \mathrm{~mL}$ of CM-Dex medium was added to the heat-treated cells and they were resuspended; $0.1 \mathrm{~mL}$ of the suspension was spread on CM-Dex agar medium, and the viability of the cells was examined. The stability of dsRNA in the producing cells was evaluated by preparing total RNA from the cells after standing at $20{ }^{\circ} \mathrm{C}$ for an additional $24 \mathrm{~h}$ after the heat treatment and examining it by PAGE.

\section{Feeding of microbial cells and evaluation of vital activities of $H$. vigintioctopunctata}

Sterilized C. glutamicum cells (60 mg wet weight) were rinsed with $1 \mathrm{~mL}$ of water twice and suspended in $50 \mu \mathrm{L}$ of sterilized water; $0.5 \mu \mathrm{L}$ of the suspension was spotted on a siliconized glass slide $(76 \times 26 \mathrm{~mm})$ and fed to an early third instar larva of $H$. vigintioctopunctata that had been starved after the second molt. After feeding, the larva was transferred onto a potato leaf and raised for $24 \mathrm{~h}$. After that, the larva was transferred to new potato leaf and the rearing was continued for another $24 \mathrm{~h}$. As evaluation indexes of the effect of administration of the dsRNA, the area of leaf eaten was measured in the periods $0-24$ and $24-48 \mathrm{~h}$ after feeding the $C$. glutamicum cells, and the body weight of the larvae was examined at $48 \mathrm{~h}$. To measure the feeding area of leaf (i.e., the area that had been eaten), a digital microscope system (VHX-5000, KEYENCE, Osaka, Japan) was used, and an analytical balance (AUW120D, Shimadzu, Kyoto, Japan) was employed for body weight measurement. We performed the Welch's $t$ test to verify the differences of effects of diapl RNAi assay. The Holm's method was applied in the multiple comparisons. The significance level in our analysis was $P$ value $<0.05$. All statistical analyses were performed by R-3.4.2 (https://cran.rproject.org/).

\section{qPCR}

Total RNA was extracted from the whole body of $H$. vigintioctopunctata using TRI Reagent (Molecular Research Center, Cincinnati, OH, USA), and DNase I treatment (1 units; New England Biolabs, Beverly, MA) was performed at $37{ }^{\circ} \mathrm{C}$ for $30 \mathrm{~min}$ in order to thoroughly degrade genomic DNA that might be contaminated in the RNA solution. First-strand cDNA was synthesized from $1 \mu \mathrm{g}$ of the total RNA using SuperScript III Reverse Transcriptase (Life Technologies, Tokyo, Japan) and primer P19. qPCR was performed using THUNDERBIRD SYBR qPCR Mix (Toyobo) according to the manufacturer's protocol in a LightCycler 96 instrument (Roche, Basel, Switzerland). The expression level of diap1 relative to the internal control, ribosomal protein 49 gene (rp49; accession number: AB480201), was calculated by the $2^{-\Delta \Delta C t}$ method (Livak and Schmittgen 2001); primer pairs $\mathrm{P} 17$ and P18, and P15 and P16, were used respectively (nucleotides 1649-1783 of diap1-cDNA [Supplemental Fig. S1]; Chikami et al. 2019). We performed Welch's $t$ test to evaluate the qPCR analysis using R-3.4.2. The $P$ values were adjusted by Holm's method in the multiple comparison, and we adopted $P<0.05$ as the significance level. 


\section{Results}

\section{Construction of diap $1 *$-dsRNA overproduction system}

The diapl gene in $H$. vigintioctopunctata was selected as a target gene for RNAi action in the pest, and a 346-bp region of diap1-cDNA (DDBJ acc. no. LC473084, nucleotides 8861231 in Supplemental Fig. S1) was employed for production of diap $1 *$-dsRNA. For the dsRNA overexpression, we adapted a convergent transcription system using a pair of strong F1 promoters from corynephage BFK20. The expression unit was cloned into a high-copy number vector, $\mathrm{pVC} 7 \mathrm{H} 2$, to yield plasmid pVH2-HvIap-1 for the diap1 *dsRNA overexpression (Fig. 1a). After the plasmid was introduced into $C$. glutamicum 2256L $\Delta r n c$, the transformant was cultured in a test tube and the total RNA was extracted for investigation of production of the target dsRNA. C. glutamicum 2256L $\Delta r n c$ harboring pVH2-HvIap-1 produced a target RNA species having the expected length (about 360 bp) (Fig. 1b).

Then, we examined the structural features of the produced RNA by processing reactions with RNase A and RNase III. RNase $\mathrm{A}$ is an endoribonuclease that specifically degrades ssRNA at pyrimidine nucleotides, while RNase III is a dsRNA-specific endonuclease. The results indicated that the RNA species produced by this system had a double-stranded structure because the RNA was decomposed by RNase III but not by RNase A (Fig. 2). In C. glutamicum 2256L (an rnc ${ }^{+}$ strain) harboring pVH2-HvIap-1, PAGE analysis of the total RNA fraction did not detect an RNA species of the expected
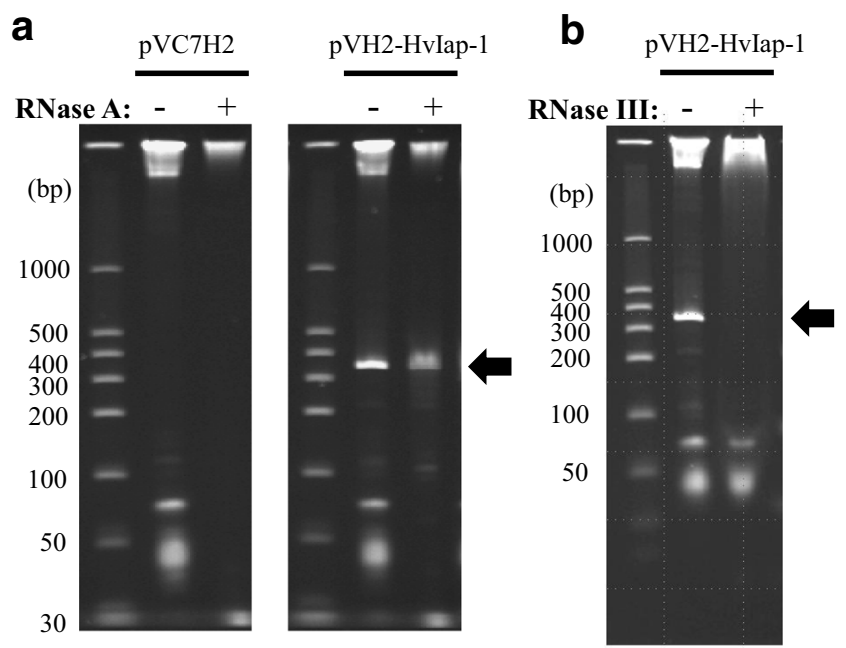

Fig. 2 Identification of diap $1 *$-dsRNA produced in C. glutamicum. Structural analysis of the produced RNA with RNase A (a) and RNase III (b). Total RNA from C. glutamicum strain 2256L $\Delta r n c$ harboring pVC7H2 or pVH2-HvIap-1 was prepared, and then, each RNA sample treated with RNase (plus sign) or not treated (minus sign) was subjected to $6 \%$ PAGE. Prominent RNA bands corresponding to diap $1 *$-dsRNA are indicated with black arrows. Size marker of dsRNAs is also shown size but instead showed products that appeared to be degraded (Supplemental Fig. S3); this also suggested that the RNA species produced in the $\mathrm{rnc}^{-}$strain (C. glutamicum $2256 \mathrm{~L} \Delta r n c$ ) had a double-stranded structure. In addition, RT-PCR using a pair of primers specific to the target coding region of diap1-cDNA (Supplemental Fig. S2b) showed the produced RNA chain had the nucleotide sequence of the region targeting the diap1 gene (Supplemental Fig. S2), judging from the result that the size of the PCR product was consistent with the DNA length expected to be amplified by the primers used. Therefore, we concluded that the RNA produced was a dsRNA containing the desired mRNA region from the target gene diap1. Taken together, these data show that the constructed expression system can efficiently produce diapl $*_{\text {- }}$ dsRNA.

\section{Production of diap 1 *-dsRNA in C. glutamicum in a fermentor}

In response to large sample preparations for future experiments using $H$. vigintioctopunctata, we performed batch culture of the $\operatorname{diap} 1{ }^{*}$-dsRNA-producing strain in a jar fermentor. Typical growth curves of the $\operatorname{diap} 1 *$-dsRNA producing strains and the control strains harboring vector $\mathrm{pVC} 7 \mathrm{H} 2$ are shown in Fig. 3a, each using three transformants. Although the cell density of all strains reached $\mathrm{OD}_{620} \approx 100$ as the maximum value, the RNA-producing strains and the control strains consumed $40 \mathrm{~g}$ of L-glucose by 26 and $30 \mathrm{~h}$ of fermentation, respectively. The total RNA was extracted from cultured cells at several time points during the cultivation and the RNA content was analyzed by PAGE. A representative result is shown in Fig. 3b. The target diap $1 *$-dsRNA accumulated as a major and discrete RNA species as the culture progressed. In the latter period of the fermentation, the presence of RNA species that appeared to be degradation products of $\operatorname{diap} 1 *$-dsRNA was observed at a low level. In addition, some products at higher molecular weight than the original diap $1 *$-dsRNA band were faintly detectable by PAGE. However, it was clear that the dsRNA-expressing microbes could efficiently accumulate the desired $\operatorname{diap} 1 *$-dsRNA within the cells. We obtained a maximum yield of about $75 \mathrm{mg}$ per liter of culture of the diap $1 *$-dsRNA in this fermentation, and we could prepare $C$. glutamicum accumulating the target diap $1 *$-dsRNA within cells.

The stability of the plasmids maintained by the cells was examined. In the control strains, almost no segregates were observed even in the last stage of the culture, and the copy number of the vector plasmid was maintained at about 300 as originally determined. However, in the culture of the diap $1 *_{-}$ dsRNA expressing strains, the fraction of cells harboring pVH2-HvIap-1 was reduced to around half, suggesting some maintenance instability of the RNA expression plasmid in this strain. 


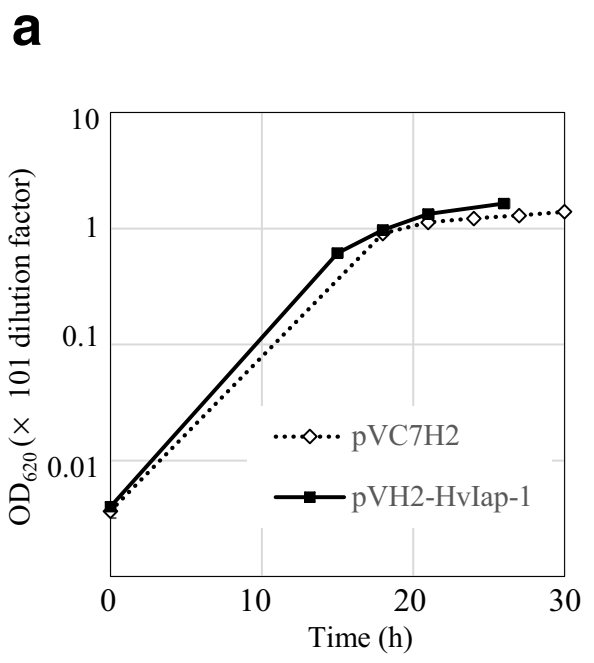

Fig. 3 Production of diap $1^{*}$-dsRNA by C. glutamicum in batch fermentation. a Growth of $C$. glutamicum $2256 \mathrm{~L} \Delta r n c$ harboring pVC7H2 as a control or pVH2-HvIap-1. Average values and standard deviations (SDs) for three independent experiments are shown, although the variation range is too small to distinguish the SDs on the graph. b PAGE analysis of total RNA prepared from each C. glutamicum strain

\section{Treatment of C. glutamicum with alcohol or heating}

As a first step in the preparation of sterilized microbes containing dsRNA, we examined the ethanol concentration required to sterilize C. glutamicum cells producing diap $1 *$ dsRNA. Generally, ethanol concentration of around $80 \%$ is most effective for the sterilization of microorganisms (Suchomel and Rotter 2011; McDonnell and Russell 1999); thus, we investigated whether such conditions could also be applied to the sterilization of $C$. glutamicum accumulating the dsRNA in this study. The treatment conditions were tentatively set such that the bacterial concentration was about $10^{9}$ cells/ $\mathrm{mL}$, and the treatment temperature and duration were $20^{\circ} \mathrm{C}$ and $10 \mathrm{~min}$, respectively. The survival of C. glutamicum cells was found to be very low at $\geq 30 \%(\mathrm{v} / \mathrm{v})$ ethanol (Supplemental Table S2); not one microbial colony appeared on the detection agar-medium plates, indicating that the survival rate of the cells was at most $10^{-8}$.

Next, the stability of the dsRNA within the sterilized cells was examined. C. glutamicum cells were separately treated with ethanol at concentrations from 30 to $95 \%(\mathrm{v} / \mathrm{v})$. Each collected cell pellet was incubated at $20{ }^{\circ} \mathrm{C}$ for an additional $24 \mathrm{~h}$, and then, total RNA was extracted from the individual tubes and subjected to PAGE to examine the integrity of the target dsRNA. Decomposition of the dsRNA hardly occurred when the ethanol concentration was $\geq 50 \%$ (v/v) (Supplemental Fig. S4). When dsRNA-producing cells not treated with ethanol were left to incubate in a similar way (as a negative control), or when the ethanol concentration was $\leq 30 \%(\mathrm{v} / \mathrm{v})$, significant RNA degradation was observed. Therefore, considering the stabilization of the dsRNA in the

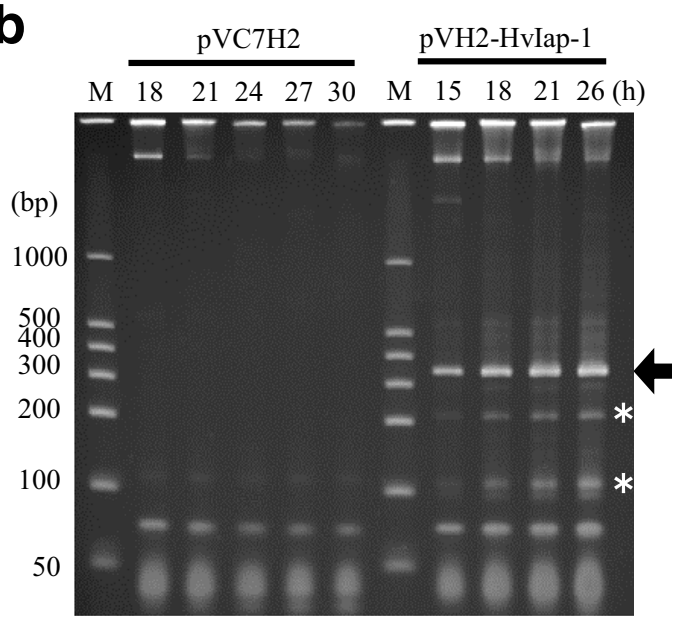

during the fermentation. Lane M shows dsRNA marker, and each culture time (h) is indicated at the top of the gel. The arrow and asterisks indicate the positions of diap $1 *$-dsRNA and its possible degradation products, respectively. The result presents one representative diapl*-dsRNA production experiment in a jar fermentor

sterilized microbe as an index of effectiveness, we chose $80 \%$ $(\mathrm{v} / \mathrm{v})$ for ethanol treatment of the dsRNA-producing strain of C. glutamicum (Fig. 4).

In a similar way as for ethanol, the survival of C. glutamicum cells in methanol and its effect on dsRNA accumulation in the cells were investigated. Sterilization of the microbes and intactness of the dsRNA were observed when the methanol concentration was $\geq 70 \%(\mathrm{v} / \mathrm{v})$ (Supplemental Fig. S5); 80\% (v/v) methanol was chosen for treatment of dsRNA-producing C. glutamicum cells (Fig. 4), according to the concentration used for ethanol treatment.

Sterilization of the cells by heating was also assessed. It was necessary to treat $C$. glutamicum cells at $100{ }^{\circ} \mathrm{C}$ for at least $30 \mathrm{~min}$ for complete killing of the microbes in a microreaction tube in a heat block. Heat killing of the cells resulted in severe degradation of RNAs, including the target diap $1 *$-dsRNA (Fig. 4).

\section{Effect of ingestion of sterilized cells containing diap 1 *-dsRNA on vital activity of the pest $H$. vigintioctopunctata}

To examine the effect of diap $l^{*}$-dsRNA on $H$. vigintioctopunctata, ethanol-sterilized $C$. glutamicum cells containing the dsRNA were suspended in a small amount of water and fed to third instar larvae of the pest. In the control groups, only water or sterilized cells containing empty vector (pVC7H2) was fed to the pest. First, the expression level in each pest of the diap1 gene targeted by the RNAi action was assayed by qPCR. Total RNA was prepared from the whole body using larval individuals reared for $48 \mathrm{~h}$ after ingestion of 


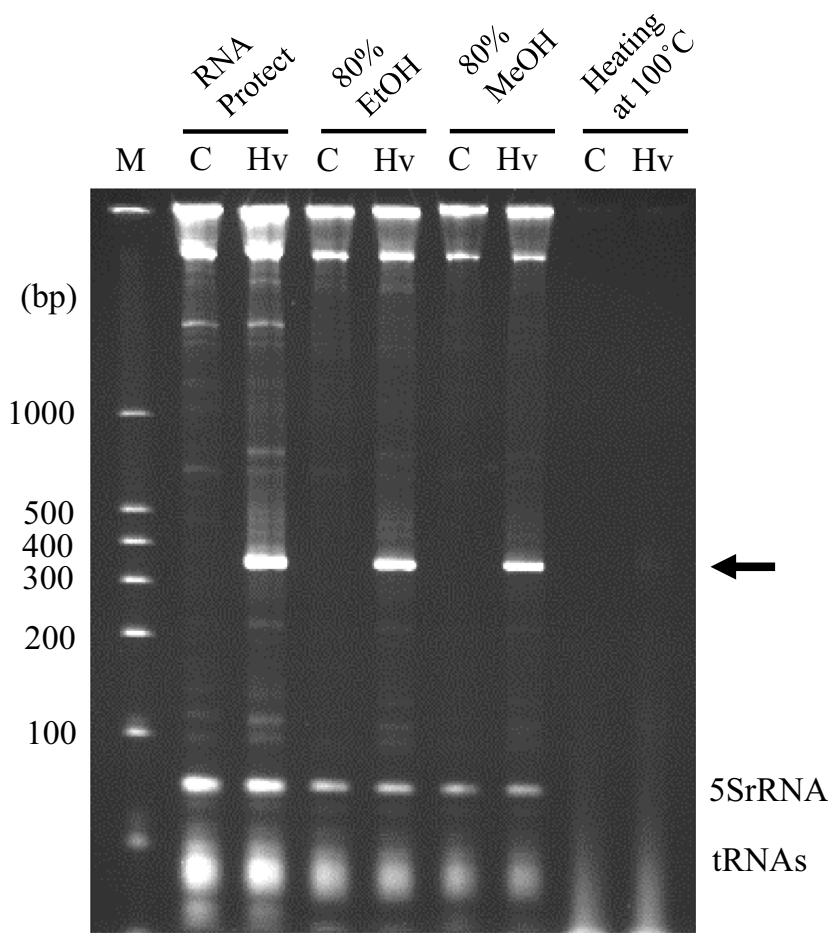

Fig. 4 Analysis of RNAs extracted from C. glutamicum cells treated with alcohol or by heating. Lanes $\mathrm{C}$ and $\mathrm{Hv}$ indicate total RNA fractions from C. glutamicum cells harboring $\mathrm{pVC} 7 \mathrm{H} 2$ as a control and pVH2-HvIap1, respectively. Lane M shows RNA size markers. "RNA protect" indicates RNA fractions extracted from microbial cells treated immediately with RNA Protect Bacteria Reagent without alcohol or heating treatment. Each treatment method applied for the sterilization is indicated at the top of the gel. RNA samples were analyzed on nondenaturing $6 \%$ PAGE, and the position of diap $1 *$-dsRNA is indicated by a black arrow

each sample (water only, control sterilized cells, or sterilized cells containing the dsRNA) and then subjected to qPCR. diapl expression in $H$. vigintioctopunctata in the group of larvae fed the control sterilized cells was significantly reduced by approx. 59\%, compared with those fed water. In the larvae fed sterilized cells containing diap1*-dsRNA, the diap1 expression level was further decreased to approx. $21 \%$ of that in those fed water (Fig. 5). These results indicated that intake of sterilized C. glutamicum cells itself caused physiological changes associated with reduction of diapl expression in the pest. It was also demonstrated that the presence of diapl* dsRNA could further suppress diap1 expression in the larvae.

Next, changes in eating of potato leaves by treated $H$. vigintioctopunctata larvae were examined. Larvae in the control group, which ingested only water, consumed about $10 \mathrm{~mm}^{2}$ after rearing for $24 \mathrm{~h}$, and about $16 \mathrm{~mm}^{2}$ during 24 $48 \mathrm{~h}$ after water intake (Fig. 6). C. glutamicum cells carrying only the vector $\mathrm{pVC} 7 \mathrm{H} 2$ were treated by each of the three sterilization methods (ethanol, methanol, or heating), and these were given to the pest larvae. When compared with the control (water) group, no significant difference in the amount of leaf eating was observed (Fig. 6; Supplemental Table S3). However, in the case of larvae fed sterilized cells containing

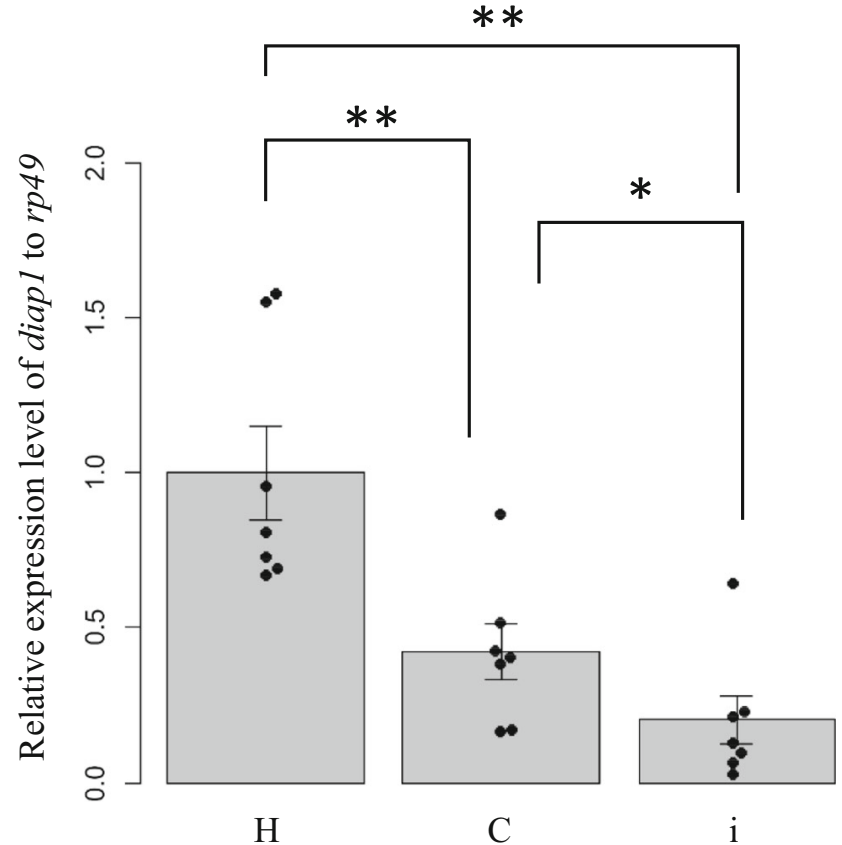

Fig. 5 Evaluation of diap1 gene expression in H. vigintioctopunctata by qPCR. The relative gene expression level of diapl to rp49 as a control was examined. The samples were prepared from whole bodies of larvae that ingested only water $(\mathrm{H})$, ethanol-sterilized cells harboring $\mathrm{pVC} 7 \mathrm{H} 2$ vector $(\mathrm{C})$, and ethanol-sterilized cells harboring pVH2-HvIap-1 (i), respectively. Statistical significance was calculated using Welch's $t$ test. The data represent the mean \pm standard error $(\mathrm{SE})(n=7) . * P<0.05$, $* * P<0.01$

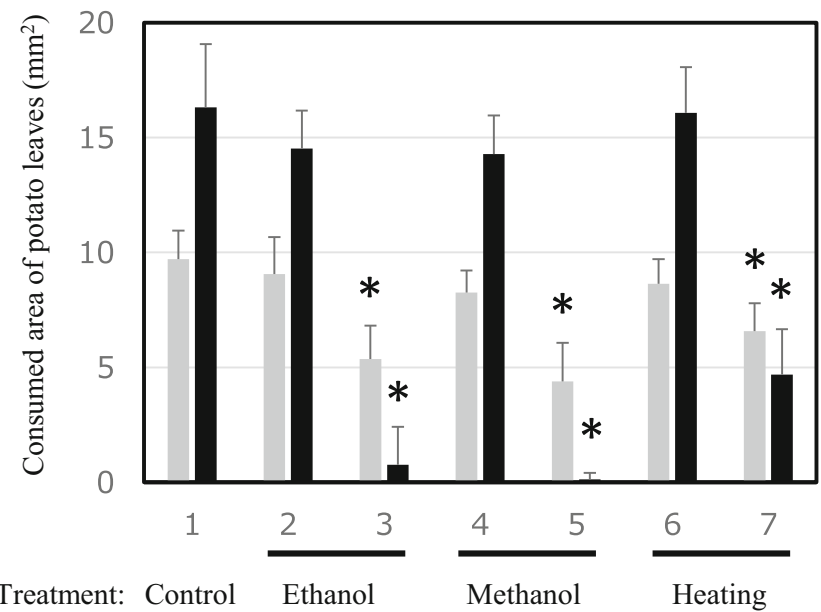

Fig. 6 Effect of feeding H. vigintioctopunctata diap $1 *$-dsRNAproducing $C$. glutamicum cells treated with alcohol or by heating on leaf consumption activity. After feeding the sample, the areas of leaf consumed during hours $0-24$ (gray bars) and subsequently during hours 24 48 (black bars) were measured. Sample 1, larvae fed water as a control; 2, 4, 6, larvae fed C. glutamicum 2256L $\Delta r n c$ cells harboring pVC7H2 vector; $3,5,7$, larvae fed $C$. glutamicum 2256L $\Delta r n c$ cells harboring $\mathrm{pVH} 2$-HvIap-1. The data are presented as the mean $\pm \mathrm{SD}$. For each group, 4-5 larvae were used. Asterisks indicate significant differences $(P<0.05)$ from corresponding values for the strain harboring only vector 
diap $1 *$-dsRNA, a significant reduction in the eating of potato leaves was observed regardless of the $C$. glutamicum cell killing method (Fig. 6; Supplemental Table S4). It was also shown that the feeding activity of the pests was reduced more by the intake of cells prepared by sterilization with alcohol than with cells killed by heating. In particular, feeding activity of larvae was hardly observed after $24 \mathrm{~h}$ after intake of cells sterilized with alcohol (Figs. 6 and 7).

Furthermore, the effect of intake of sterilized C. glutamicum cells containing diap $1 *$-dsRNA on the growth of larva was evaluated using changes in the body weight as an index. In controls, water only was given to the third instar larva. The average weight after rearing them on potato leaves for $48 \mathrm{~h}$ was about $8 \mathrm{mg}$ (Fig. 8). The weight value was almost the same in the group fed cells containing the vector only. When sterilized cells containing diap $1 *$-dsRNA were fed, the average weights were significantly lower, regardless of the C. glutamicum sterilization method, and only slight growth was observed from the larvae of the start stage in the experiment (Supplemental Table S4). The body weight of the larvae was lower when fed microbial cells sterilized with alcohol than heat-killed cells (Fig. 8).

Taken together, these results indicated that $C$. glutamicum cells containing $\operatorname{diap} 1{ }^{*}$-dsRNA sterilized with alcohol were able to significantly suppress the vital activity of $H$. vigintioctopunctata larvae. In the case of this pest at least, alcohol-treated $C$. glutamicum cells could be used as capsules containing target dsRNA, which could be applied as a new biopesticide.

\section{Discussion}

In previous study, we constructed an expression system that can produce large amounts of recombinant RNA using C. glutamicum as the host microbe (Hashiro et al. 2019b).

\section{a}

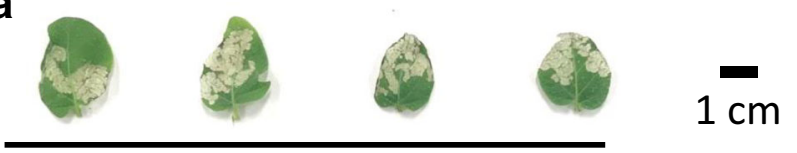

b

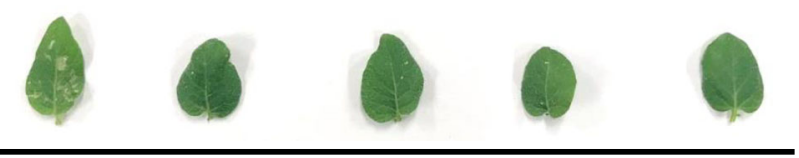

Fig. 7 Damage to potato leaves by larvae of $H$. vigintioctopunctata and its suppression by feeding sterilized microbial cells containing diap ${ }^{*}$ dsRNA to the pest. C. glutamicum cells harboring $\mathrm{pVC7H2}$ vector (a) or pVH2-HvIap1 (b) were treated with $80 \%$ ethanol for sterilization and then fed to $H$. vigintioctopunctata larvae. The status of potato leaves eaten between 24 and $48 \mathrm{~h}$ after the feeding of sterilized cells to the larvae is shown. A typical result from four to five leaves from each experimental group is presented. Scale bar, $1 \mathrm{~cm}$

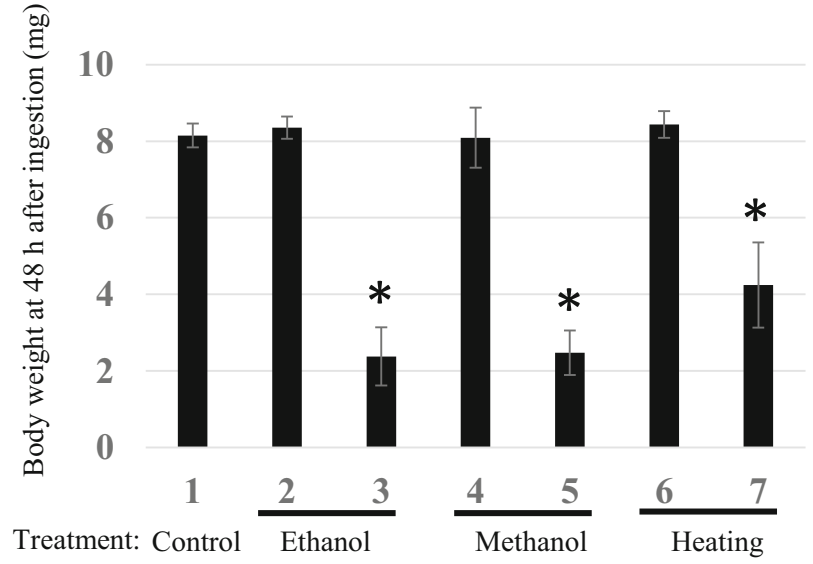

Fig. 8 Evaluation of larval body weight of $H$. vigintioctopunctata $48 \mathrm{~h}$ after ingestion of $C$. glutamicum cells sterilized by alcohol or heating. Sample 1, larvae fed water (negative control); 2, 4, 6, larvae fed C. glutamicum $2256 \mathrm{~L} \Delta r n c$ cells harboring pVC7H2 vector; 3, 5, 7, larvae fed $C$. glutamicum 2256L $\Delta r n c$ cells harboring pVH2-HvIap-1. The data are presented as the mean $\pm \mathrm{SD}$. For each group, 4-5 larvae were used. Asterisks indicate significant differences $(P<0.05)$ from corresponding values for the strain harboring only vector

Here, based on this overexpression system, we adopted a convergent transcription system for producing dsRNA to suppress diapl gene expression in a target insect, $H$. vigintioctopunctata; high productivity of recombinant dsRNA was obtained (around $75 \mathrm{mg} / \mathrm{L}$ ) (Figs. 1 and 3). In the RNA expression system, no special transcriptional terminators were used for termination of strong transcription from the phage-derived promoter F1, but each complementary ssRNA transcribed from the target RNA-coding region on the expression plasmid was inferred to be paired immediately after transcription and trimmed by some kind of RNase in vivo. Thus, the target dsRNA appeared to be efficiently accumulated in this convergent expression system in C. glutamicum (Fig. 3). Several studies on dsRNA production by a convergent transcription system using T7-RNA polymerase/the T7 promoter in E. coli strain HT115 (rnc ${ }^{-}$) have been reported (Wan et al. 2015; Zhu et al. 2011; Ratzka et al. 2013), but the production levels of target dsRNAs remain obscure, although Tenllado et al. (2003) stated that their target dsRNA production using the E. coli/T7 system was about $4 \mathrm{mg} / \mathrm{L}$ of culture medium. In many studies on pest growth control using dsRNA, the various target dsRNA species have been prepared using in vitro transcription systems. However, such an approach is obviously expensive and not suitable for the production of large amounts of target dsRNAs. In that respect, our microbial dsRNA production system could be applicable for large-scale dsRNA production for field testing of the dsRNA. C. glutamicum is a nonpathogenic, "Generally Recognized as Safe" microbe, used globally for fermentative production of huge amounts of amino acids (Lee and Wendisch 2017; Ikeda and Takeno 2013; Yasueda 2014), indicating that this microbe is robust. It seems that 
C. glutamicum is also very suitable for mass production of recombinant RNA molecules at low cost.

We showed inhibition of the growth of $H$. vigintioctopunctata larvae by direct ingestion of dsRNA for RNAi of the diap1 gene in previous work (Niimi et al. 2015; Chikami et al. 2019). Here, it has been demonstrated that the vital activity of this pest can be suppressed even by feeding it sterilized microbial cells containing diap $1 *$-dsRNA. It is known that the growth of Colorado potato beetle (CPB), Leptinotarsa decemlineata, a famous crop pest, is also affected adversely by suppression of target gene expression due to feeding of dsRNA (Sun Miguel and Scott 2016; Wan et al. 2015). In particular, Zhu et al. (2011) treated E. coli cells which produced a target dsRNA for suppressing the growth of $\mathrm{CPB}$ with heating to sterilize the microbes, and then the treated cells were sprayed onto foliage to show their effectiveness as a pesticide. The method is an effective means to provide target dsRNA for pest control at low cost. However, in heating treatment for sterilization, if the volume of the object to be heated is large, the thermal conductivity to the whole object is somewhat slow, and thus, it might be difficult to ensure uniformity of heating of the whole of the reactant to be processed. Therefore, to completely sterilize the objective microbial cells by heating, it is supposed that excessively heated cells are formed, in which the target RNA can be decomposed. Our experiments with C. glutamicum cells support this conclusion as we observed substantial RNA degradation during heat treatment (Fig. 4), although the result might have been specific to the heat-sterilizing conditions or host strain used in this study. As an alternative simple and efficient sterilization method, we studied sterilization of C. glutamicum while maintaining the integrity of dsRNA accumulated inside the cells by using ethanol or methanol. In particular, ethanol is a disinfectant widely used in food hygiene, and the use of ethanol in the preparation of such an RNA insecticide will have relatively little environmental burden. These alcohols rapidly permeate into the inside of microbial cells while destroying part of the cell membrane structure, thereby causing denaturation of proteins in the microbe (McDonnell and Russell 1999). This could effectively suppress the activity of RNA-degrading enzymes remaining in the producing microbial cells. Thus, it seems that nucleic acids are partially dehydrated by alcohol and then are stabilized inside the microbial cell bodies. In addition, this treatment can be carried out at room temperature or below, therefore suppressing degradation of the RNA molecules during this treatment process.

However, the membrane structure of the microbial cells is still maintained to some extent by this treatment process, and it is expected that the packaging of the target dsRNA by the treated cell envelope plays a role in protecting the internal dsRNA against, for example, exogenous RNases and ultraviolet rays. The ladybird beetles that ingested sterilized C. glutamicum cells containing diap $1 *$-dsRNA no longer ate potato leaves voraciously, and their weight gain was suppressed (Figs. 6, 7, and 8). As these microbial cells can be used as capsules enclosing the target dsRNA, their insecticidal effect after spraying in agricultural fields should be evaluated. In heat-treated $C$. glutamicum cells, the RNA species were considerably degraded. However, feeding larvae these heatprocessed cells containing diap $1 *$-dsRNA still inhibited larval growth to some extent (Figs. 6 and 8). Since the RNA chain length actually required for RNAi action is about $21-23 \mathrm{bp}$, it is possible that some of the dsRNA fragments degraded by this heat treatment retained the length required for RNAi action.

In the case of the diap1 gene, the phenotype that $H$. vigintioctopunctata feeding activity was suppressed appeared in a short period after ingestion of the dsRNA-containing C. glutamicum cells (Fig. 6), indicating that diap1 is an excellent candidate gene as a target for an RNA-based pesticide (Niimi et al. 2015; Chikami et al. 2019). From the results of qPCR quantification of diap1 expression in the pest, it was shown that the expression was significantly reduced even in larvae fed sterilized cells not containing diap $1{ }^{*}$-dsRNA (compared with the control larvae that only ingested water) (Fig. 5). However, no remarkable change was found in the leaf-feeding activity or weight gain of such larvae compared with wateringesting control larvae (Figs. 6 and 8). Thus, the reduction in diap1 expression in the larvae fed microbes that did not contain $\operatorname{diap} 1 *$-dsRNA may be fluctuation of gene expression due to normal physiological responses to ingested bacteria or their fragments in the pest midgut. Although there is not yet sufficient knowledge about physiological actions, including immune responses, to exogenous bacteria in the midgut of ladybird beetles including $H$. vigintioctopunctata, there are some reports of responses to infectious bacteria in Drosophila gut (Buchon et al. 2009). In that insect, reactive oxygen species (ROS) are produced to eliminate bacteria that have invaded the gut, but the ROS also damage gut epithelial cells of the insect. Intestinal stem cells divide and proliferate rapidly to repair the damage to the tissue, and the appearance of apoptotic cells has been confirmed in the gut (Buchon et al. 2009). Therefore, in our present study, it is plausible that diap1 expression in intestinal cells was physiologically suppressed by the signal of bacterial invasion, as a normal response. An immune response to infectious bacteria in the gut of Drosophila is induced by sensing peptidoglycan (PG), which constitutes the bacterial cell wall, through PG recognition proteins (Kurata 2014). C. glutamicum, which is a Grampositive bacterium, is covered with a thick layer of mycolic acids (MA) on the outside of the cell but has a PG layer on the inside of the MA layer (Lanéelle et al. 2013). Therefore, it can be inferred that such an immune response may be triggered when the microbes enter the midgut of $H$. vigintioctopunctata even if the microbes are not alive. It is important to note, however, our data show that the reduction in diap1 expression 
caused by the ingestion of diap $1{ }^{*}$-dsRNA is an enforced reduction in specific gene expression, not the normal physiological response of $H$. vigintioctopunctata to foreign bacterial bodies. Thus, $H$. vigintioctopunctata that ingest diap $1 *_{-}$ dsRNA suffer marked inhibition of their biological activity. It has not been confirmed here that the target pest is killed by the intake of the diap $1 *$-dsRNA; we speculate that this RNAi acts only in certain cells of the pest body and thus does not lead to rapid death of the pest (at least in the third instar larval stage, as used in our experiments). However, this dsRNA was shown to be able to exert the function of suppressing crop damage, which is crucial for a pesticide.

Since the dsRNA-producing C. glutamicum cells used in this study were sterilized until below the detection limit of live microbial cells, they would not be classified as living modified organisms (LMOs) based on the standard definition (Husby 2007). However, this RNA expression system carries a chloramphenicol resistance gene on a plasmid within the dead microbe. It will therefore be desirable to use a new selection marker in place of an antibiotic resistance gene marker, for example, the combination of a gene encoding an essential metabolic enzyme of the microbe on a plasmid and deficiency of that gene in the chromosome of the host microbial cell. In this fermentation test, it was found that the maintenance stability of the dsRNA expression plasmid in the production strain was not perfect. Indeed, in the culture of the dsRNAproducing strain, the time taken for complete consumption of glucose was shorter and the OD value of cells reached was slightly higher, compared with the control strain. This is probably the result of the emergence of segregates that have lost the expression plasmid. In the late stage of culture, the fact that the antibiotic concentration in the medium was below the action limit would be the cause of appearance of the segregates. Therefore, by using the plasmid maintenance approach described above, plasmid stability could be also improved, which will further increase production and accumulation of the target RNA.

RNAi acts specifically on a target gene sequence, and, therefore, RNA-based pesticides exert their action only on the target pest or an organism having the same sequence in a gene. The high specificity of target action suggests that the use of RNA-based pesticides is unlikely to result in side effects on beneficial insects such as honeybees. In addition, when resistance to a certain RNA-based pesticide appears in the target pest, newly effective ones could be produced rapidly, since it is sufficient to modify the base sequence of the dsRNA used. Taken together, this system for production of dsRNAs and their preparation is expected to contribute to a significant reduction in the cost of supplying dsRNAs that act on target agricultural pests, and we believe that the methods described in this paper provide an effective means of applying such dsRNAs as RNA-based pesticides in agriculture in the near future.
Acknowledgments The authors are grateful to A. Ando (WDB-Eureka) and Y. Iseki (Persol Tempstaff Co.) for their technical assistance, and we thank Drs. Y. Kawahara, K. Onomichi (Ajinomoto Co.) and T. Sato (University of Tsukuba) for their support and encouragement in promoting this research. We thank James Allen, DPhil, from Edanz Group for editing a draft of this manuscript.

Author contributions H. Y. conceived this study, and S. H., T. N., and H. Y. designed the experiments. S. H. and M. M. carried out the genetic engineering and fermentation studies of microbial strains. H. K. and Y. C. performed the studies on insect biology and associated analyses. H. Y. and T. N. supervised the research. H. Y., T. N., and S. H. wrote the manuscript, and all authors approved the final manuscript.

\section{Compliance with ethical standards}

Conflict of interest S. Hashiro, M. Mitsuhashi, H. Kawaguchi, T. Niimi, and $\mathrm{H}$. Yasueda: An international patent on the RNA production was applied for as PCT/JP2019/006324. Y. Chikami declares no competing interests.

Ethical approval This article does not contain any studies with human participants or vertebrates performed by any of the authors.

Open Access This article is distributed under the terms of the Creative Commons Attribution 4.0 International License (http:// creativecommons.org/licenses/by/4.0/), which permits unrestricted use, distribution, and reproduction in any medium, provided you give appropriate credit to the original author(s) and the source, provide a link to the Creative Commons license, and indicate if changes were made.

\section{References}

Alyokhin A, Baker M, Mota-Sanchez D, Dively G, Grafius E (2008) Colorado potato beetle resistance to insecticides. Am J Potato Res 85:395-413. https://doi.org/10.1007/s12230-008-9052-0

Bolognesi R, Ramaseshadri P, Anderson J, Bachman P, Clinton W, Flannagan R, Ilagan O, Lawrence C, Levine S, Moar W, Mueller G, Tan J, Uffman J, Wiggins E, Heck G, Segers G (2012) Characterizing the mechanism of action of double-stranded RNA activity against western corn rootworm (Diabrotica virgifera virgifera LeConte). PLoS One 7:e47534. https://doi.org/10.1371/ journal.pone. 0047534

Buchon N, Broderick NA, Poidevin M, Pradervand S, Lemaitre B (2009) Drosophila intestinal response to bacterial infection: activation of host defense and stem cell proliferation. Cell Host Microbe 5:200 211. https://doi.org/10.1016/j.chom.2009.01.003

Chikami Y, Kawaguchi H, Suzuki T, Yoshioka H, Sato Y, Yaginuma T, Niimi T (2019) Acute feeding disorder after oral RNAi exposure results in efficient pest control. bioRxiv. https://doi.org/10.1101/ 737643

Chinen A, Kozlov YI, Hara Y, Izui H, Yasueda H (2007) Innovative metabolic pathway design for efficient ${ }_{\mathrm{L}}$-glutamate production by suppressing $\mathrm{CO}_{2}$ emission. J Biosci Bioeng 103:262-269. https:// doi.org/10.1263/jbb.103.262

Christiaens O, Prentice K, Pertry I, Ghislain M, Bailey A, Niblett C, Gheysen G, Smagghe G (2016) RNA interference: a promising biopesticide strategy against the African sweetpotato weevil Cylas brunneus. Sci Rep 6:38836. https://doi.org/10.1038/srep38836

Gu L, Knipple DC (2013) Recent advances in RNA interference research in insects: implications for future insect pest management strategies. Crop Prot 45:36-40. https://doi.org/10.1016/j.cropro.2012.10.004 
Hashiro S, Mitsuhashi M, Yasueda H (2019a) High copy number mutants derived from Corynebacterium glutamicum cryptic plasmid pAM330 and copy number control. J Biosci Bioeng 127:529-538. https://doi.org/10.1016/j.jbiosc.2018.10.012

Hashiro S, Mitsuhashi M, Yasueda H (2019b) Overexpression system for recombinant RNA in Corynebacterium glutamicum using a strong promoter derived from corynephage BFK20. J Biosci Bioeng 128: 255-263. https://doi.org/10.1016/j.jbiosc.2019.03.003

Hashiro S, Yasueda H (2018) Plasmid copy number mutation in repA gene encoding RepA replication initiator of cryptic plasmid pHM1519 in Corynebacterium glutamicum. Biosci Biotechnol Biochem 82:2212-2224. https://doi.org/10.1080/09168451.2018. 1508986

Husby J (2007) Chapter 23 definition of GMO/LMO and modern biotechnology. In: Traavik T, Ching LL (eds) Biosafety first. Tapir Academic Publishers, Trondheim, pp 365-373

Ikeda M, Takeno S (2013) Amino acid production by Corynebacterium glutamicum. In: Yukawa H, Inui M (eds) Corynebacterium glutamicum. Biology and Biotechnology. Springer-Verlag, Berlin Heidelberg, pp 107-147

Jeyasankar A, Premalatha S, Elumalai K (2014) Antifeedant and insecticidal activities of selected plant extracts against Epilachna beetle, Henosepilachna vigintioctopunctata (Coleoptera: Coccinellidae). Adv Entomol 2:14-19. https://doi.org/10.4236/ae.2014.21003

Katoch R, Sethi A, Thakur N, Murdock LL (2013) RNAi for insect control: current perspective and future challenges. Appl Biochem Biotechnol 171:847-873. https://doi.org/10.1007/s12010-0130399-4

Knorr E, Fishilevich E, Tenbusch L, Frey MLF, Rangasamy M, Billion A, Worden SE, Gandra P, Arora K, Lo W, Schulenberg G, ValverdeGarcia P, Vilcinskas A, Narva KE (2018) Gene silencing in Tribolium castaneum as a tool for the targeted identification of candidate RNAi targets in crop pests. Sci Rep 8:2061. https://doi.org/ 10.1038/s41598-018-20416-y

Kumar S, Cakouros D (2004) Transcriptional control of the core celldeath machinery. Trends Biochem Sci 29:193-199. https://doi.org/ 10.1016/j.tibs.2004.02.001

Kurata S (2014) Peptidoglycan recognition proteins in Drosophila immunity. Dev Comp Immunol 42:36-41. https://doi.org/10.1016/j.dci. 2013.06.006

Lanéelle M, Tropis M, Daffé M (2013) Current knowledge on mycolic acids in Corynebacterium glutamicum and their relevance for biotechnological processes. Appl Microbiol Biotechnol 97:9923-9930. https://doi.org/10.1007/s00253-013-5265-3

Lee J, Wendisch VF (2017) Production of amino acids - genetic and metabolic engineering approaches. Bioresour Technol 245:15751587. https://doi.org/10.1016/j.biortech.2017.05.065

Livak KJ, Schmittgen TD (2001) Analysis of relative gene expression data using real-time quantitative PCR and the $2^{-\Delta \Delta C}$ T method. Methods 25:402-408. https://doi.org/10.1006/meth.2001.1262

McDonnell G, Russell AD (1999) Antiseptics and disinfectants: activity, action, and resistance. Clin Microbiol Rev 12:147-179

Mitter N, Worrall EA, Robinson KE, Li P, Jain RG, Taochy C, Fletcher SJ, Carroll BJ, Lu GQ, Xu ZP (2017) Clay nanosheets for topical delivery of RNAi for sustained protection against plant viruses. Nat Plants 3. https://doi.org/10.1038/nplants.2016.207

Niimi T, Yoshioka H, Sato Y (2015) Insect pest control method. US. Patent US 9051569B2. (Date of patent: June 9, 2015)

Nishio Y, Koseki C, Tonouchi N, Matsui K, Sugimoto S, Usuda Y (2017) Analysis of strain-specific genes in glutamic acid-producing
Corynebacterium glutamicum ssp. lactofermentum AJ 1511. J Gen Appl Microbiol 63:157-164. https://doi.org/10.2323/jgam.2016.09. 004

Palli SR (2014) RNA interference in Colorado potato beetle: steps toward development of dsRNA as a commercial insecticide. Curr Opin Insect Sci 6:1-8. https://doi.org/10.1016/j.cois.2014.09.011

Ratzka C, Gross R, Feldhaar H (2013) Systemic gene knockdown in Camponotus floridanus workers by feeding of dsRNA. Insect Soc 60:475-484. https://doi.org/10.1007/s00040-013-0314-6

Suchomel M, Rotter M (2011) Ethanol in pre-surgical hand rubs: concentration and duration of application for achieving European Norm EN 12791. J Hosp Infect 77:263-266. https://doi.org/10.1016/j.jhin. 2010.10 .014

Sun Miguel K, Scott JG (2016) The next generation of insecticides: dsRNA is stable as a foliar-applied insecticide. Pest Manag Sci 72: 801-809. https://doi.org/10.1002/ps.4056

Tariq K, Ali A, Davies TGE, Naz E, Naz L, Sohail S, Hou M, Ullah F (2019) RNA interference-mediated knockdown of voltage-gated sodium channel $\left(M p N a_{v}\right)$ gene causes mortality in peach-potato aphid, Myzus persicae. Sci Rep 9:5291. https://doi.org/10.1038/s41598$019-41832-8$

Tenllado F, Martínez-García B, Vargas M, Díaz-Ruíz JR (2003) Crude extracts of bacterially expressed dsRNA can be used to protect plants against virus infections. BMC Biotechnol 3:3. https://doi. org/10.1186/1472-6750-3-3

Venkatesha MG (2006) Seasonal occurrence of Henosepilachna vigintioctopunctata (F.) (Coleoptera: Coccinellidae) and its parasitoid on Ashwagandha in India. J Asia Pac Entomol 9:265-268. https://doi.org/10.1016/S1226-8615(08)60301-5

Wan P, Fu K, Lü F, Wang X, Guo W, Li G (2015) Knocking down a putative $\Delta^{1}$-pyrroline-5-carboxylate dehydrogenase gene by RNA interference inhibits flight and causes adult lethality in the Colorado potato beetle Leptinotarsa decemlineata (Say). Pest Manag Sci 71: 1387-1396. https://doi.org/10.1002/ps.3941

Wang Z, Wang X, Li C, Xia Z, Li S (2018) Effect of dietary protein and carbohydrates on survival and growth in larvae of the Henosepilachna vigintioctopunctata (F.) (Coleoptera: Coccinellidae). J Insect Sci 18:1-7. https://doi.org/10.1093/jisesa/ iey067

Woodcock BA, Isaac NJB, Bullock JM, Roy DB, Garthwaite DG, Crowe A, Pywell RF (2016) Impacts of neonicotinoid use on long-term population changes in wild bees in England. Nat Commun 7. https://doi.org/10.1038/ncomms 12459

Yasueda H (2014) Overproduction of ${ }_{\mathrm{L}}$-glutamate in Corynebacterium glutamicum. In: Anazawa H, Shimizu S (eds) Microbial production: from genome design to cell engineering. Springer, Tokyo, pp 165176

Zhou X, Wheeler MM, Oi FM, Scharf ME (2008) RNA interference in the termite Reticulitermes flavipes through ingestion of doublestranded RNA. Insect Biochem Mol Biol 38:805-815. https://doi. org/10.1016/j.ibmb.2008.05.005

Zhu F, Xu J, Palli R, Ferguson J, Palli SR (2011) Ingested RNA interference for managing the populations of the Colorado potato beetle, Leptinotarsa decemlineata. Pest Manag Sci 67:175-182. https://doi. org/10.1002/ps.2048

Publisher's note Springer Nature remains neutral with regard to jurisdictional claims in published maps and institutional affiliations. 